\title{
OD „MADE IN CHINA” DO „CREATED IN CHINA” - DROGA CHIN DO SUPREMACJI INNOWACYJNEJ
}

\author{
Wstęp
}

Przyjęta w 1978 r. chińska polityka „otwartych drzwi”, która była integralną częścią reform gospodarczych, skutkowała stopniowym otwieraniem się na handel i inwestycje zagraniczne, czego efektem było przystapienie Chin do W'TO w 2001 r. Obecnie chiński handel bez wątpienia wpływa na światowe rynki. Chiny to już nie tylko kraj taniej produkcji „made in China”, ponieważ Państwo Środka staje się coraz bardziej innowacyjne, o czym świadczy wzrost pozycji w corocznym rankingu Global Innovation Index (GII).

W ostatniej dekadzie Chiny stały się wschodzacym mocarstwem, przy jednoczesnym osłabieniu gospodarczej pozycji Stanów Zjednoczonych i Unii Europejskiej. Paradoksalnie pandemia, która według wielu analityków miała pogrążyć nadzieje Chin na zdobycie statusu globalnego mocarstwa, obnażając przy tym niewydolność ich systemu politycznego, relatywnie wzmocniła ten kraj. Państwo Środka zakończyło rok 2020 ze wzrostem PKB na poziomie 2,3\%, a także z rekordowym eksportem napędzanym rosnącym popytem na towary elektroniczne i sprzęt medyczny. Dodatkowo Chiny wyprzedzily Stany Zjednoczone w rankingu głównych odbiorców zagranicznych inwestycji bezpośrednich. „Przedcovidowe” prognozy wskazywały, że Chiny staną się największą gospodarką świata w 2035 r. Jednak spowodowana ogłoszeniem pandemii recesja w Stanach Zjednoczonych, przy równoczesnym wzroście PKB Chin, może przybliżyć ten moment nawet o 7 lat ${ }^{1}$. Poczucie stabilności Państwa Środka wynika m.in. z posiadania bogatych złóż metali rzadkich oraz ogromnych rezerw walutowych. Natomiast wyzwaniem dla chińskiej gospodarki są: pułapka średniego dochodu $^{2}$, zadłużenie ${ }^{3}$, korupcja czy też słabe strony ekosystemu innowacji ${ }^{4}$.

\footnotetext{
ORCID: 0000-0002-7850-9101, DOI: 10.4467/23538724GS.20.052.13492

1 P. Paszak, Chiny - nieoczekiwany wygrany pandemii?, https://warsawinstitute.org (dostęp: 20.02.2021).

2 M. Schuman, Cbiny jednak utknq w pułapce średniego dochodu? Oto wielka przesžkoda rozwojowa Państwa Środka, https://forsal.pl (dostęp: 20.02.2021).

3 W. Gadomski, Chiny w pułapce zadtu̇̌enia, www.obserwatorfinansowy.pl (dostęp: 20.02.2021).

4 C. Jia, X. Tang, Z. Kan, Does the Nation Innovation System in China Support the Sustainability of Small and Medium Enterprises (SMEs) Innovation?, „Sustainability” 2020, no. 12.
} 
Głównym celem niniejszego artykułu jest próba odpowiedzi na pytanie, czy supremacja innowacyjna Stanów Zjednoczonych przechodzi do przeszłości. Aby na nie odpowiedzieć, sformułowane zostały następujące hipotezy: 1) supremacja innowacyjna Stanów Zjednoczonych kończy się na skutek wzrostu roli Chin; 2) rola Chin rośnie w efekcie odejścia od „made in China” i nielegalnie pozyskiwanych rozwiązań technologicznych na rzecz innowacyjności i produkcji zaawansowanej technologicznie, czyli „created in China”. Analiza została przeprowadzona w kontekście znaczenia pułapki Tukidydesa w technologicznej wojnie między Stanami Zjednoczonymi a Chinami oraz umiejscowienia zmian w innowacyjności obu krajów w aspekcie cyklu Kondratiewa. Punktem wyjścia niniejszych rozważań jest porównanie innowacyjności Chin i Stanów Zjednoczonych na podstawie Global Innovation Index 2020.

\section{Miejsce Chin w globalnym krajobrazie innowacyjności przez pryzmat GII 2020}

Historia kształtowania się chińskiej innowacyjności rozpoczęła się tysiące lat temu. Dość wspomnieć, że ok. 3 tys. lat przed narodzeniem Chrystusa odkrycie w Chinach jedwabiu uruchomiło słynny Jedwabny Szlak, a dopiero w V w. n.e. tajemnica produkcji jedwabiu wydostała się poza Państwo Środka. Lista powstających w tamtych czasach chińskich wynalazków, do których zalicza się m.in. porcelanę, proch, papier, kompas czy ster, była bardzo długa i wskazywała na, liczone często w setkach lat, relatywne zacofanie Zachodu w wielu dziedzinach ${ }^{5}$. Chiny były wówczas w centrum uwagi świata. Można powiedzieć, że obecnie historia zatacza koło i Chiny - po tysiącleciach czasów świetności na skalę światową oraz parokrotnych, potencjalnie unicestwiających kraj turbulencjach mających miejsce w XX w. - ponownie znajduja się w centrum uwagi całego świata ${ }^{6}$.

Według prognoz do roku 2030 mają zajść na świecie ogromne zmiany zarówno ilościowe, jak i jakościowe określane mianem „,wielkiej transformacji”, która będzie polegała na dominacji znaczenia Chin oraz pozostałych krajów ACI, czyli ASEAN i Indii w gospodarce światowej, przy jednoczesnym obniżeniu roli pozostałych krajów świata ${ }^{7}$. Prognozy te wpisują się w obserwowany w ostatnich latach spektakularny wzrost zaawansowania technologicznego w Chinach. Z jednej strony chiński model rozwoju służy przyspieszonemu rozwojowi społeczno-gospodarczemu Pań-

5 Gavin, The Four Great Inventions of Ancient China, www.chinahighlights.com (dostęp: 20.02.2021).

6 W. Hübner, Innowacje w Chinach: od starożytności do wyzwań dnia dżisiejszego, „Kwartalnik Naukowy Uczelni Vistula" 2013, nr 2 (36).

P.A. Petri, F. Zhai, Navigating a Changing World Economy: ASEAN, the People's Republic of China, and India, ADBI Working Paper No. 404, 23.01.2013. 
stwa Środka, ale wiąże się z ogromnymi kosztami społecznymi i ekologicznymi ${ }^{8}$. $\mathrm{Z}$ drugiej strony rosnąca przewaga technologiczna Chin postrzegana jest jako zagrożenie dla bezpieczeństwa narodowego Stanów Zjednoczonych, co prowadzi do wojny technologicznej jako elementu wojny handlowej, toczącej się już od kilku lat.

Wśród metod oceny innowacyjności krajów znajduje się Globalny Indeks Innowacyjności (Global Innovation Index, GII), publikowany corocznie, począwszy od 2007 r. Indeks ma ogólnoświatowy wymiar i umożliwia porównanie innowacyjności gospodarek metoda min-max, która pozwala na ich uplasowanie w skali od 0 do 100. GII opracowany jest przez Światową Organizację Własności Intelektualnej ONZ (WIPO), Uniwersytet Cornell's SC Johnson College of Business oraz Szkołę Biznesu INSEAD. Lista rankingowa obejmuje obecnie 131 krajów?

Global Innovation Index składa się z dwóch subindeksów. Jeden z nich dotyczy działań innowacyjnych, czyli nakładów (subindeks wejścia) i w jego skład wchodzi 5 filarów, drugi natomiast to subindeks wyjścia skupiający się na wynikach (efektach innowacyjnych), który jest zbudowany z 2 filarów. Każdy z filarów obejmuje po 3 kategorie, a w ich ramach znajduje się od 2 do 5 podkategorii, które składają się łącznie na 80 wskaźników innowacyjności. Największą grupa, bo stanowiącą prawie $70 \%$ wszystkich wskaźników, są wskaźniki obiektywne (ilościowe, twarde dane), sprzężone z podstawowymi charakterystykami gospodarczymi, np. z wartością PKB, powierzchnia, liczbą ludności danego kraju. Druga grupa to wskaźniki złożone (indeksy agregatowe), a ostatnia to wskaźniki subiektywne (jakościowe, miękkie dane), których jest 5 .

W najnowszym rankingu GII 2020 znajdują się tradycyjne wskaźniki, takie jak: wydatki na badania i rozwój czy wnioski patentowe, ale również nowe wskaźniki, do których zalicza się np. tworzenie aplikacji mobilnych. Ranking ukazuje zaawansowanie krajów pod względem ich innowacyjności oraz określa współczynnik efektywności innowacji. Wskaźnik GII stanowi średnią arytmetyczną subindeksów wejścia oraz wyjścia. Natomiast wskaźnik efektywności innowacyjności definiowany jest jako iloraz subindeksu wyjścia do subindeksu wejścia i stanowi podstawę rankingu innowacyjności państw. Do subindeksu wejścia zalicza się: instytucje, kapitał ludzki i badania, infrastrukturę, zaawansowanie rynku i zaawansowanie biznesu. Natomiast subindeks wyjścia tworzony jest przez filar wiedzy i rezultatów technologicznych oraz wyników kreatywności. Na rys. 1 przedstawione zostały 2 subindeksy oraz 7 filarów budujących globalny indeks innowacyjności GII. Podstawową rolą GII jest ukazanie pozycji poszczególnych krajów w globalnym wielowymiarowym krajobrazie innowacyjności. Dogłębna analiza poszczególnych elementów składowych mierników syntetycznych, w odniesieniu

\footnotetext{
8 M. Walkowski, Chinski model rozwoju spoteczno-gospodarczego i jego potencjalna adaptacja w Europie, „Przegląd Strategiczny” 2017, nr 10, s. 27.

9 The Global Innovation Index (GII) 2020, www.globalinnovationindex.org (dostęp: 20.02.2021).
} 


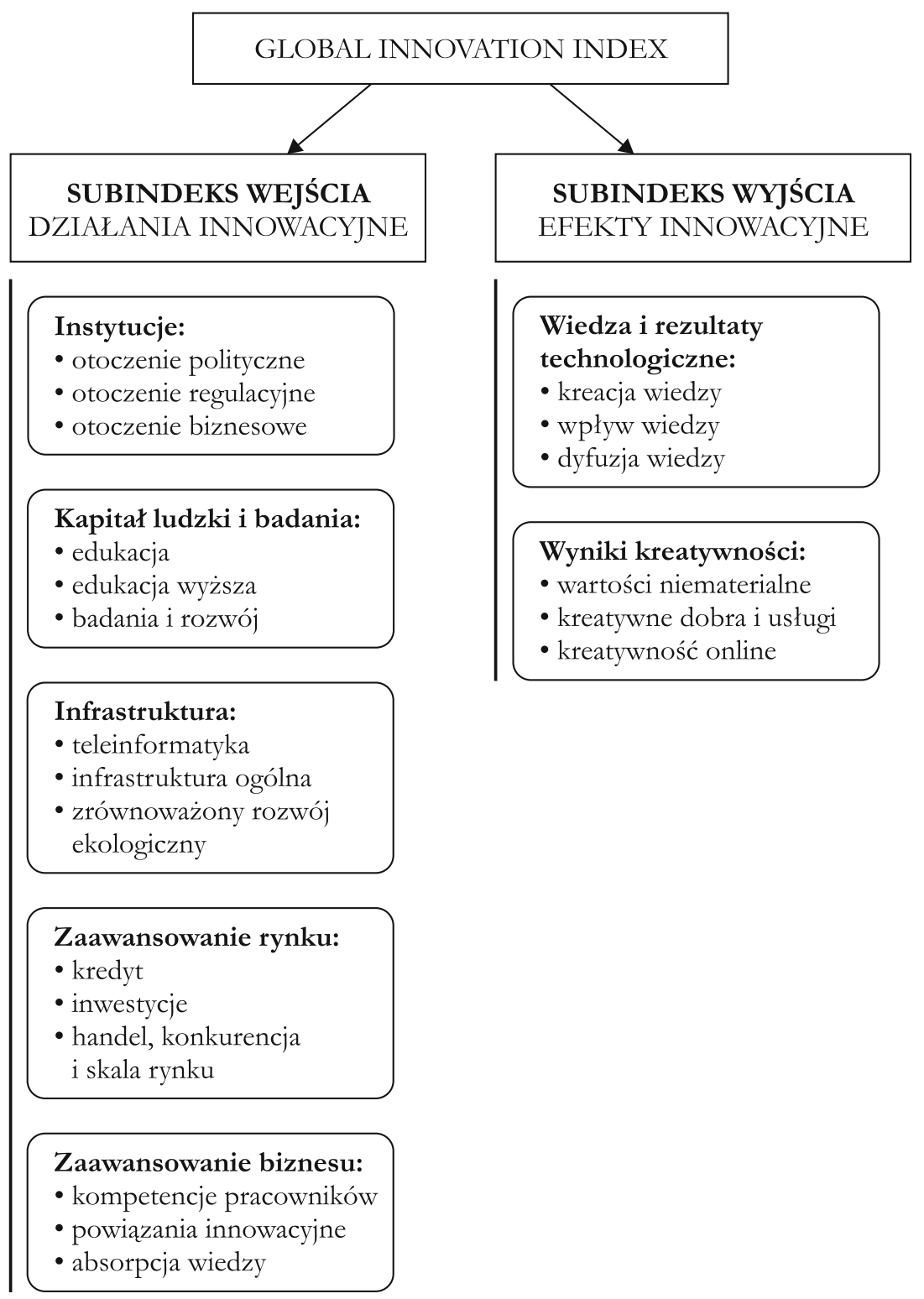

Rys. 1. Filary Global Innovation Index

Źródło: Opracowanie własne na podstawie: The Global Innovation Index (GII) 2020, www.globalinnovationindex.org (dostęp: 20.02.2021). 
do każdego kraju, pozwala natomiast na wyodrębnienie mocnych i słabych stron innowacyjności, przyczyniając się do kreowania polityki innowacyjnej, której celem jest wspieranie innowacyjnego rozwoju ${ }^{10}$.

Global Innovation Index potwierdza, że wysoki stopień innowacyjności osiagają te kraje, które charakteryzują się silną gospodarką mierzoną poziomem dochodów (rys. 2). Jednocześnie gospodarka Chin przewyższa spodziewane wyniki parametru innowacyjności w odniesieniu do aktualnego poziomu rozwoju gospodarczego. Chiny charakteryzuja się bowiem bardzo wysoką efektywnością gospodarki $(0,92)$, co dało im pierwszą lokatę w GII 2020 w ogólnym zestawieniu efektywności innowacyjnej (rys. 3). Stany Zjednoczone ze wskaźnikiem 0,8 znalazły się na miejscu 13. Jednocześnie Chiny zajęły 14. pozycję w ogólnym indeksie GII, wyróżniając się tym, że jako jedyny kraj wśród pierwszych 32 innowatorów nie są sklasyfikowane jako gospodarka o wysokich dochodach (na 33. miejscu jest Malezja - będąca podobnie jak Chiny krajem o średnich dochodach $)^{11}$. Należy podkreślić, że jeszcze 7 lat temu Chiny zajmowały 35. lokatę, a 4 lata temu były na miejscu 25. Widoczny na rys. 2 trend malejący oznacza wzrost miejsca Chin w Globalnym Indeksie Innowacyjności. Stany Zjednoczone znajdują się na miejscu 3. W zestawieniu Global Innovation Index 2020 1. miejsce zajęła Szwajcaria, wyprzedzając Szwecję i wspomniane Stany Zjednoczone. Jeśli chodzi o subindeks wejścia, to przewaga Stanów Zjednoczonych jest niezaprzeczalna (rys. 4), natomiast w przypadku subindeksu wyjścia obie gospodarki w ostatnich 2 latach bardzo się do siebie zbliżyły (rys. 5).

Po przeanalizowaniu 7 filarów GII 2020 (tab. 1) okazuje się, że Chiny przewyższają Stany Zjednoczone tylko w 4 z 21 obszarów. W zakresie działań innowacyjnych jest to infrastruktura ogólna, do której zalicza się produkcję energii elektrycznej czy wydajność logistyczna; zrównoważony rozwój ekologiczny, obejmujący stopień realizacji celów polityki środowiskowej i otrzymane certyfikaty 14001 dotyczące systemu zarządzania środowiskowego oraz, w aspekcie zaawansowania biznesu, kompetencje pracowników (m.in. odsetek przedsiębiorstw oferujących programy szkoleniowe dla pracowników, nakłady brutto na badania i rozwój finansowane przez przedsiębiorstwa). Natomiast w subindeksie wyjścia w kategorii „wartości niematerialne" Chiny zajmuja miejsce 1., podczas gdy Stany Zjednoczone sa na miejscu 15. W obszarze tym mieści się np. liczba zgłoszeń znaków towarowych, wzorów przemysłowych i użytkowych.

\footnotetext{
${ }_{10}$ M. Grzelak, E. Roszko-Wójtowicz, Zastosowanie miedsynarodowych indeksów do oceny innowacyjności gospodarek Unii Europejskiej, „Studia Prawno-Ekonomiczne” 2017, t. CV, s. 232.

11 www.globalinnovationindex.org/gii-2020-report (dostęp: 20.02.2021).
} 

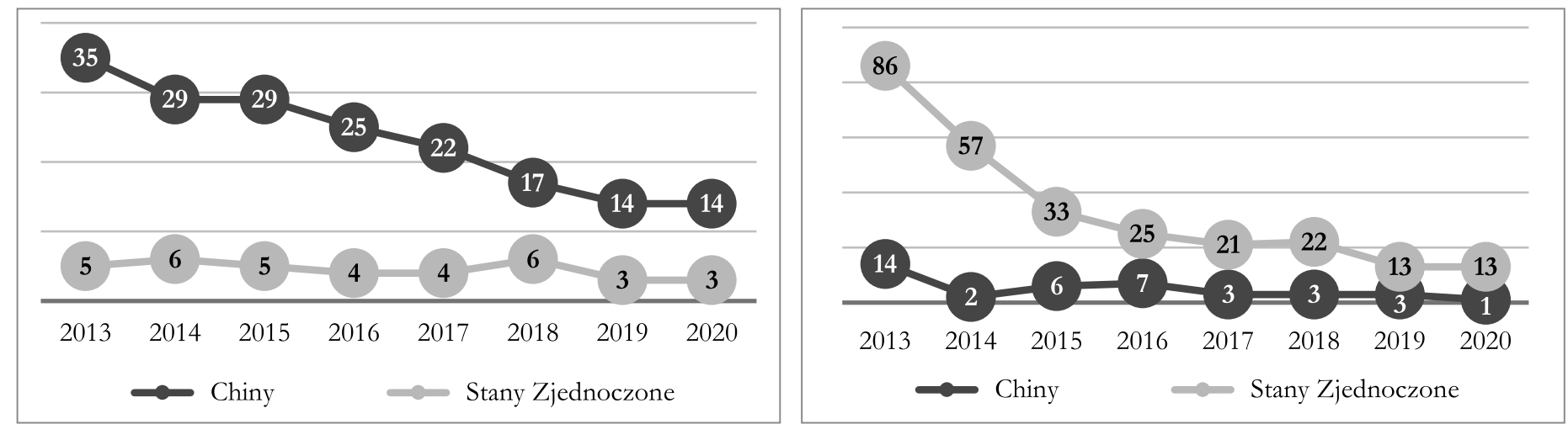

Rys. 2. Miejsce w rankingu GII 2020

Rys. 4. Miejsce w rankingu wskaźnika wejścia
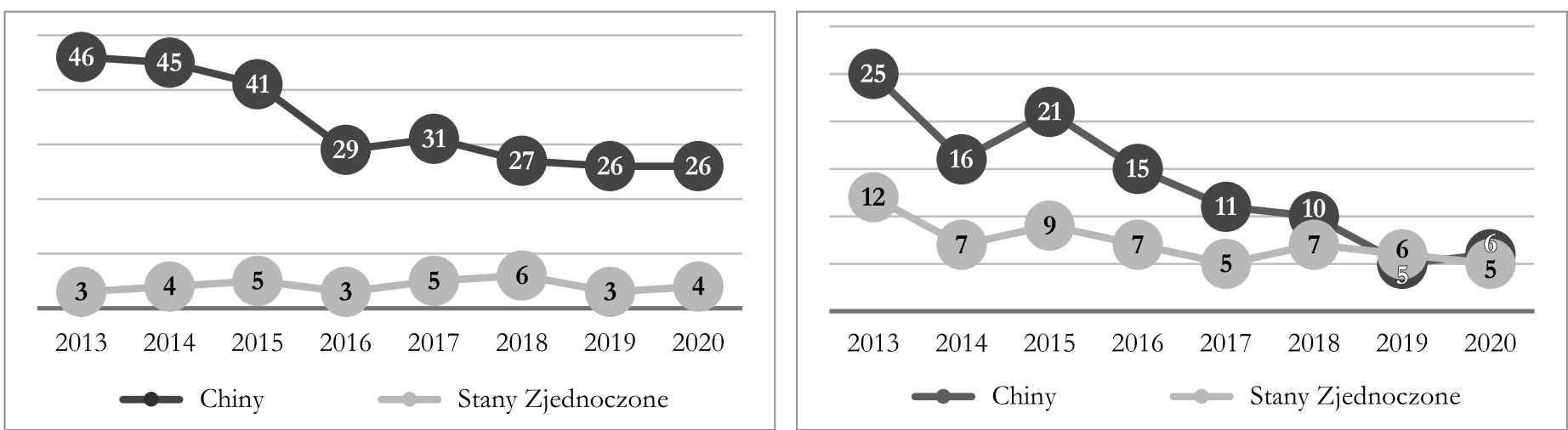

Rys. 3. Miejsce w rankingu efektywności innowacyjnej

Rys. 5. Miejsce w rankingu wskaźnika wyjścia

Źródło: Opracowanie własne na podstawie GII dla poszczególnych lat, www.globalinnovationindex.org (dostęp: 20.02.2021). 
Tab. 1. Miejsce Chin i Stanów Zjednoczonych w rankingu GII - analiza porównawcza

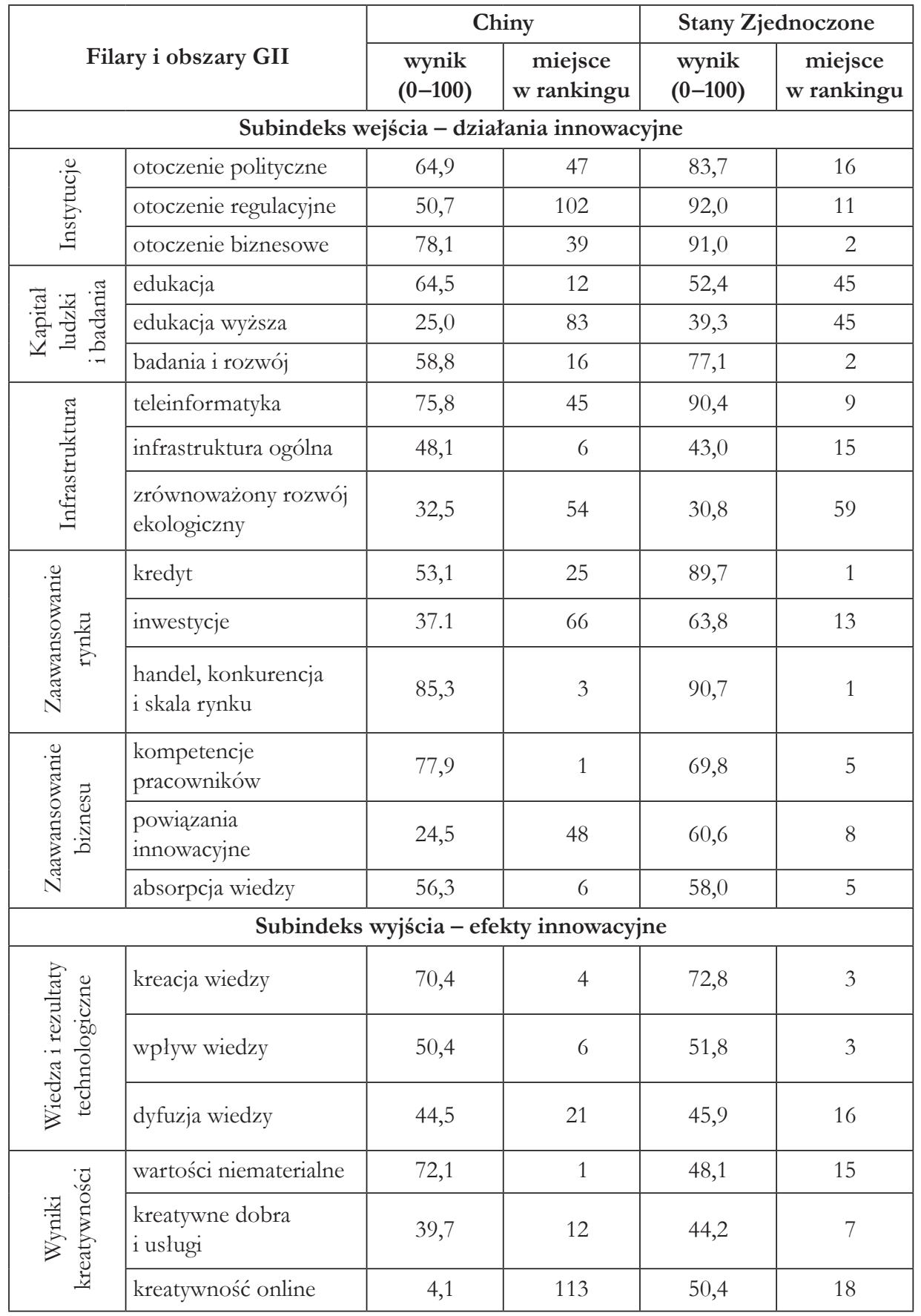


Tab. 1. cd.

\begin{tabular}{|l|c|c|c|c|}
\hline \multirow{2}{*}{ Filary i obszary GII } & \multicolumn{2}{c|}{ Chiny } & \multicolumn{2}{c|}{ Stany Zjednoczone } \\
\cline { 2 - 5 } & $\begin{array}{c}\text { wynik } \\
\mathbf{( 0 - 1 0 0 )}\end{array}$ & $\begin{array}{c}\text { miejsce } \\
\text { w rankingu }\end{array}$ & $\begin{array}{c}\text { wynik } \\
\mathbf{( 0 - 1 0 0 )}\end{array}$ & $\begin{array}{c}\text { miejsce } \\
\text { w rankingu }\end{array}$ \\
\hline \multicolumn{4}{|c|}{ Global Innovation Index } \\
\hline Ogólny wskaźnik GII & 53,3 & 14 & 60,6 & 3 \\
\hline $\begin{array}{l}\text { Wskaźnik efektywności } \\
\text { innowacyjnej }\end{array}$ & 0,9 & 1 & 0,8 & 13 \\
\hline Subindeks - wskaźnik wejścia & 55,5 & 26 & 68,8 & 4 \\
\hline Subindeks - wskaźnik wyjścia & 51,0 & 6 & 52,3 & 5 \\
\hline
\end{tabular}

Źródło: Opracowanie własne na podstawie: Global Innovation Index 2020, www.globalinnovationindex.org (dostęp: 20.02.2021).

Jak wynika $z$ danych zawartych w tab. 1, o ile w subindeksie wejścia obserwuje się znaczną różnicę pomiędzy Stanami Zjednoczonymi (4) i Chinami (26) w zakresie miejsca zajmowanego w rankingu, o tyle w przypadku subindeksu wyjścia pozycje obu krajów są do siebie zbliżone - Stany Zjednoczone zajmują miejsce 5., Chiny plasują się na miejscu 6. Innowacyjność, czyli zdolność i motywacja do permanentnego poszukiwania i wykorzystywania w praktyce wyników badań naukowych, prac badawczo-rozwojowych czy też nowych pomysłów przekłada się na konkurencyjność. Wśród metod oceny konkurencyjności gospodarek znajduje się ranking przygotowywany przez Międzynarodowy Instytut Zarządzania Rozwojem i publikowany jako World Competitiveness Yearbook ${ }^{12}$. Co ciekawe, Chiny zajmują w tym rankingu 14. miejsce, czyli takie samo jak w przypadku GII, zaś Stany Zjednoczone są na miejscu 3., za Singapurem i Hongkongiem ${ }^{13}$.

Warto również dodać, jak wynika z danych European Innovation Scoreboard $2020^{14}$, że między 2012 a 2019 r. Chiny doganiały Unię Europejską w tempie pięciokrotnie przewyższającym tempo wzrostu innowacyjności w UE. Prognozy wskazuja, że jeżeli utrzymają się obecne tendencje, to Chiny zmniejszą tę lukę jeszcze bardziej i prawdopodobnie prześcigną Stany Zjednoczone już w najbliższych latach.

Chiny przeznaczają coraz więcej środków na badania i rozwój, podnosząc jednocześnie jakość swojej produkcji, mimo że z punktu widzenia krajowych wydatków na badania i rozwój (B+R) liczonych jako procent PKB (rys. 6) czy też liczby badaczy na tysiąc zatrudnionych (rys. 7) widoczna jest przewaga Stanów Zjednoczonych nad Chinami. Wydatki Stanów Zjednoczonych na B+R wynosza

12 IMD, www.imd.org (dostęp: 20.02.2021).

13 J. Bednarz, S. Pangsy-Kania, H. Treder, Ekspansja zagraniczna przedsiebiorstw w warunkach konkurencii miédsynarodowej, Gdańsk 2020, s. 145-146.

14 European innovation scoreboard, https://ec.europa.eu (dostęp: 20.02.2021). 
$2,83 \% \mathrm{PKB}^{15}$. Wydatki Chin są zbliżone do wydatków na $\mathrm{B}+\mathrm{R}$ ponoszonych przez Francje $(2,19 \%)$ czy Norwegię $(2,06 \%)$. Średnia wydatków UE-28 była natomiast niższa niż Chin i wynosiła 2,03\%. Warto w tym kontekście zwrócić jednocześnie uwage na słabość chińskiej gospodarki na drodze do innowacyjności, która przejawia się w trudnościach w dostępie do wysoko kwalifikowanego kapitału ludzkiego, mimo że liczba badaczy na tysiąc zatrudnionych wzrosła 2,5-krotnie w porównaniu z rokiem 2000. Podobnie jest w przypadku wydatków na badania i rozwój w 2000 r. wynosiły one $0,98 \%$ PKB, zaś w 2018 r. wzrosły do 2,14\% ${ }^{16}$.

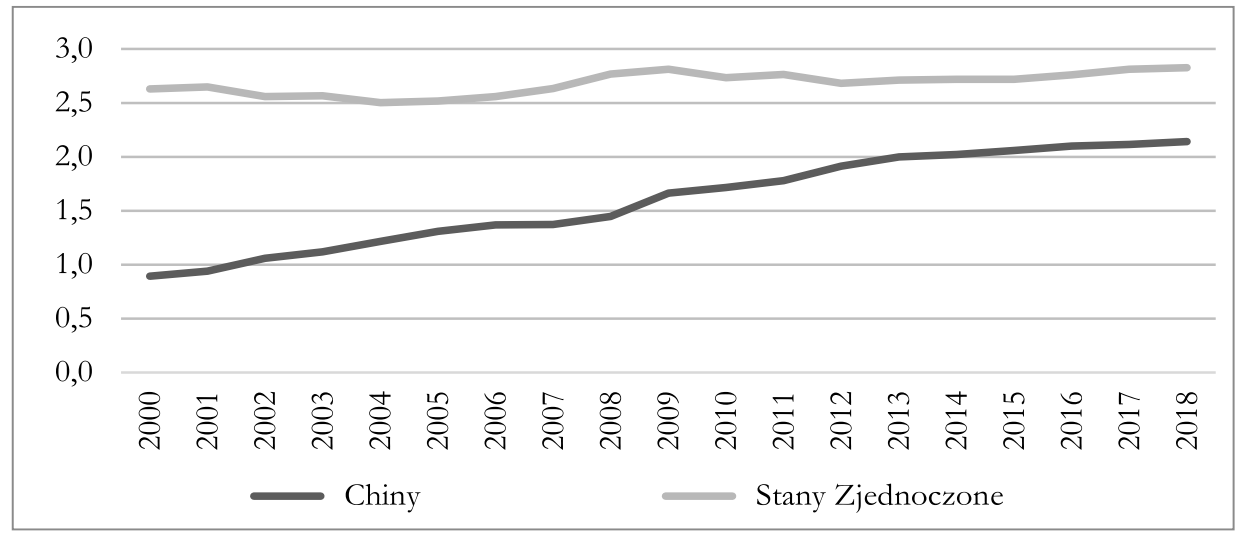

Rys. 6. Krajowe wydatki brutto na badania i rozwój (\% PKB)

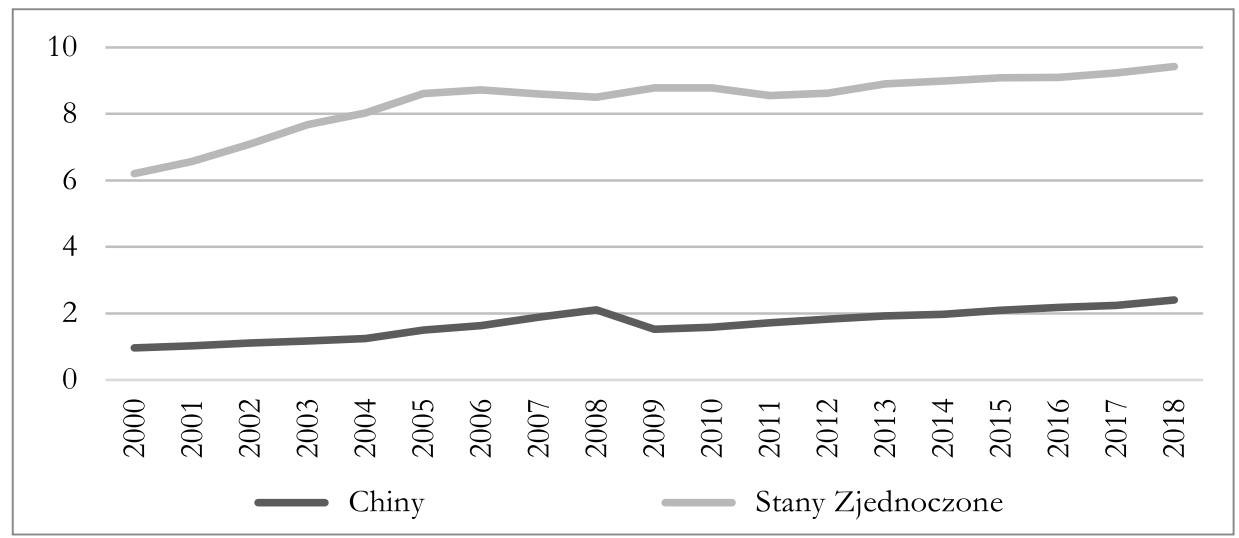

Rys. 7. Liczba badaczy na tysiąc zatrudnionych

Źródło: Opracowanie własne na podstawie danych OECD, https://data.oecd.org (dostęp: 20.02.2021).

15 Największe wydatki na B+R ponosi Izrael (4,94\%), Korea Południowa (4,53\%) i Tajwan (3,46\%), wg danych OECD: https://data.oecd.org (dostęp: 20.02.2021).

16 Ibidem. 
Początki chińskiej innowacyjności opierały się w dużym stopniu na „odwróconej" triadzie Schumpetera, która stanowi punkt wyjścia teorii twórczej destrukcji. W przypadku chińskiej gospodarki proces ten nie przebiegal jednak od inwencji poprzez innowację do imitacji, lecz odwrotnie - czyli imitacja rozwiązań (kopiowanie) prowadziła do wykreowania innowacji na rynku lokalnym, a następnie przyczyniała się do powstania nowego pomysłu (inwencji) ${ }^{17}$. Współczesna droga Chin od „made in China” do „created in China” jest bardziej „wyboista”, ponieważ wiąże się z kradzieżą własności intelektualnej ${ }^{18}$. Obecnie Chiny podejmują wiele działań mających na celu dostosowanie krajowego systemu własności intelektualnej do standardów międzynarodowych ${ }^{19}$.

Dążenie Chin, by przejść od „made in China” do „created in China”, oznacza przejście od roli światowej montowni do centrum projektowego i miejsca produkcji towarów o najwyższej wartości dodanej. Chiny znajduja się w gronie liderów w zakresie technologii telekomunikacyjnych i sztucznej inteligencji, aspirując jednocześnie do takiej roli w zakresie energetyki odnawialnej i przemysłu high-tech. Ponadto należy podkreślić dynamikę Chin w zakresie ochrony własności intelektualnej, przejawiającą się w liczbie zgłoszeń znaków towarowych do Urzędu UE ds. Własności Intelektualnej (EU-IPO), który zajmuje się ich rejestracją na europejskim wspólnym rynku. W 2020 r. liczba tych zgłoszeń wzrosła o prawie $90 \% \mathrm{w}$ porównaniu z rokiem 2019, wskazując na awans Chin w globalnym łańcuchu dostaw i umiejętność wykorzystania przez chińskie przedsiębiorstwa zawirowań w światowej gospodarce, spowodowanych ogłoszeniem pandemii. W ten sposób Chiny wyprzedziły Stany Zjednoczone, które zajmowały 2. miejsce pod względem rejestracji znaków towarowych, znajdując się zaraz za Niemcami ${ }^{20}$. Takie dążenia i nakładające się na to działania globalizacyjne, które przestały sprzyjać amerykańskim interesom, stanowią wyzwanie dla wiodącej roli Stanów Zjednoczonych w gospodarce światowej. Dążenie Chin do podniesienia pozycji w międzynarodowym podziale pracy oraz samowystarczalności technologicznej, wpisującej się w koncepcję gospodarki podwójnego obiegu (dual circulation) determinuje długookresową rywalizację pomiędzy Chinami a Stanami Zjednoczonymi. Implikacje spowodowane ogłoszeniem pandemii koronawirusa mogą spowodować eskalację konfliktu i intensyfikację rywalizacji gospodarczej, ponieważ ów konflikt jest efektem strukturalnych procesów rywalizacji geopolitycznej pomiędzy Stanami Zjednoczonymi a Chinami ${ }^{21}$. Gospodarka

17 Chiny na drodze od imitacji do innowacji, https://ideologia.pl (dostęp: 20.02.2021).

18 Stany Zjednoczone rozpoczynaja dochodzenie przeciwko Chinom za kradzież, własności intelektualnej, https://businessinsider.com.pl (dostęp: 20.02.2021).

19 M. Schmidt-Husarz, Ochrona wtasności intelektualnej w Chinach - prawda cay fikecja?, https://chiny24.com (dostęp: 20.02.2021).

20 M. Cedra, Chinski smok rozpedza sie w Europie, „Dziennik Gazeta Prawna”, 3.03.2021.

21 P. Paszak, Wojna handlowa Chiny - USA: geneza, przebieg $i$ skutki, https://warsawinstitute.org (dostęp: 20.02.2021). 
podwójnego obiegu oznacza, że dla Chin najważniejszy ma być rynek wewnętrzny, natomiast rynki światowe maja pozostać ważne, ale uzupełniające i tworzące drugi $\mathrm{obieg}^{22}$. Istotną rolę w tym modelu ma odgrywać uniezależnienie się Chin od importu półprzewodników, które mają kluczowe znaczenie m.in. dla wdrożenia technologii $5 G^{23}$. Przykładem jest inicjatywa Nanniwan ${ }^{24}$ uruchomiona przez Huawei, która ma umożliwić uniezależnienie się od rozwiązań amerykańskich ${ }^{25}$, po tym jak Stany Zjednoczone postanowiły sankcjami wyeliminować Huawei z rynku dostawców sprzętu $5 \mathrm{G}^{26}$. Można wręcz stwierdzić, że w wojnie technologicznej zwycięży ten, kto będzie potrafil samodzielnie wyprodukować i sprzedać smartfon.

Systemowa rywalizacja Państwa Środka ze Stanami Zjednoczonymi wywiera istotny wpływ na relacje pomiędzy Chinami a innymi krajami. Kwestia ograniczenia współpracy z koncernem Huawei i Chinami w aspekcie zagrożenia bezpieczeństwa narodowego doprowadziła w efekcie do wojny technologicznej między Stanami Zjednoczonymi a Chinami, stanowiącej kluczowy element wojny handlowej, która trwa już od kilku lat ${ }^{27}$. Notabene Huawei jest jednym z najbardziej innowacyjnych przedsiębiorstw na świecie ${ }^{28}$.

Wiceprezydent USA Mike Pence, wygłaszając w 2018 r. przemówienie w Instytucie Hudsona, nadał amerykańskiej wojnie handlowej z Chinami ramy ideologiczne. $O$ ile jednak w układzie zimnowojennym zagrożenie dla świata zachodniego ze strony Związku Radzieckiego rozpatrywano w kategoriach militarnych, o tyle obecne zagrożenie ze strony Chin analizowane jest głównie w aspekcie gospodarczym. Współcześnie o potędze państwa decyduje jego gospodarka. Wojna toczy się już nie o terytorium w rozumieniu ziemi, lecz przestrzeń handlowa, głównie technologiczna. Znaczenia nabiera geoekonomia, która podkreśla, że o pozycji kraju decydują jego potencjał i efektywność gospodarcza. Supremacja innowacyjna ma w tym aspekcie kluczowe znaczenie.

Dążenie Chin do supremacji innowacyjnej na świecie ma swoje odzwierciedlenie w opartych na polityce protekcjonistycznej strategiach rządowych, takich jak Made in

22 A. Sheng, Dual circulation is a strategic process, not a theory, www.eastasiaforum.org (dostęp: 20.02.2021).

23 T. Świderek, Pótpræẹvodniki potræebne (Chinom) od zaraz, www.obserwatorfinansowy.pl (dostęp: 20.02.2021).

24 Z. Yushuo, Huawei Launches Project Nanniwan to Develop US Tech-Free Devices, www.yicaiglobal. com (dostęp: 20.02.2021).

25 Huawei uruchamia projekt, który pozwoli mu uniknać amerykańskich technologii, www.komputerswiat.pl (dostęp: 20.02.2021).

26 T. Świderek, Pótprzewodniki potrzebne (Chinom)...

27 P. Tomaszewska, S. Tomaszewska, Potencjalna ,wojna handlowa” miedsy Chinami a Stanami Zjednoczonymi i jej makroekonomiczne konsekwencje, „Społeczeństwo i Polityka” 2019, nr 4 (61).

28 K. Świtalski, Huawei jedna z, najbardžiej innowacyjnych firm na świecie, https://antyweb.pl (dostęp: 20.02.2021). 
China 2025, China Standards 2035, Strategic Emerging Industries (SEI ${ }^{29}$. W centrum zainteresowania Chin znajduja się technologie informacyjne nowej generacji, w tym sztuczna inteligencja i big data, a ponadto m.in. pojazdy elektryczne, energia alternatywna, technologie środowiskowe i energooszczędne, urządzenia elektroenergetyczne, biotechnologia, nowe materiały, innowacje cyfrowe, sprzęt lotniczy i kosmiczny.

Należy podkreślić, że ogłoszenie pandemii COVID-19 wzmocniło tendencje, zgodnie z którymi centrum światowej gospodarki, handlu oraz wysokich technologii przenosi się do Azji ${ }^{30}$. Sukces Chin na drodze do innowacyjnej supremacji wydaje się zatem bardziej prawdopodobny niż porażka ${ }^{31}$. Biorąc pod uwagę chiński ekspansjonizm, konflikty na linii Stany Zjednoczone - Chiny są nieuniknione, tym bardziej że USA nie zamierzają „,bez walki” oddać pozycji hegemona ${ }^{32}$. Ryzyko przekształcenia się tej rywalizacji w wojnę, której skutkiem byłaby zmiana lidera w supremacji innowacyjnej, wynika z pułapki Tukidydesa i wpisuje się w teorię długich cykli Kondratiewa.

\section{W pułapce Tukidydesa}

Mocarstwem zagrażającym dominującej pozycji Stanów Zjednoczonych są obecnie Chiny, co przywodzi na myśl, opisana przez starożytnego greckiego historyka i filozofa - Tukidydesa, historię Sparty i Aten, które jako dwie strony konfliktu stały się zakładnikami nieuniknionej wojny. Konflikt ten wynikał ze wzrostu znaczenia Aten i lęku Sparty o utratę dominującej pozycji. Pułapka polega na tym, że w otoczeniu (współcześnie gospodarczym, tehcnologicznym, innowacyjnym) dotychczasowej dominującej gospodarki pojawia się inna gospodarka, która nie osiągnęła jeszcze pozycji dominującej, ale zagraża dotychczasowej potędze. Obawy dotyczące zagrożenia utraty pozycji supermocarstwa przez dotychczasowa potęgę czynią wojnę nieuniknioną - jak pisał Tukidydes w Historii wojny peloponeskiej. Pułapka Tukidydesa oznacza nieuchronne zmierzenie się z sobą obu krajów, ponieważ oba walczą o te same zasoby, ale nie zawsze będzie to skutkować konfliktem zbrojnym. Według G. Allisona sytuacja, gdy

29 L. Li, China's manufacturing locus in 2025: With a comparison of "Made-in-China 2025" and "Industry 4.0”, „Technological Forecasting and Social Change. An International Journal” 2018, vol. 135, s. 66-74; A.Ch. Koty, What is the China Standards 2035 Plan and How Will it Impact Emerging Industries?, www.china-briefing.com (dostęp: 20.02.2021); F. Tang, China unveils 'strategic emerging industries' plan in fresh push to get away from US technologies, www.scmp.com (dostęp: 20.02.2021).

30 B. Góralczyk, Świat skupia się w Ažji, www.obserwatorfinansowy.pl (dostęp: 20.02.2021).

31 J. Zhang, Rok 2021 będzie poczatkiem totalnej wojny miedzy Chinami a Zachodem o gospodarcze praywódzৃtwo nad swiatem. Tyle ìe Zachód tego nie rozumie, https://wiadomosci.onet.pl/opinie (dostęp: 20.02.2021).

32 R. Kruszyński, US A - ChRL: konflikt konieczny?, „Przegląd Bezpieczeństwa Wewnętrznego” 2020, nr 23 (12). 
wschodzące mocarstwo zagrażało dominacji dotychczasowej potęgi, zdarzyła się w ciagu ostatnich 500 lat 16 razy, przy czym tylko w 4 przypadkach nie doszło do konfliktu zbrojnego (wojny) ${ }^{33}$, co zostało przedstawione w tab. 2.

Tab. 2. Efekty pułapki Tukidydesa

\begin{tabular}{|r|l|l|l|l|}
\hline Lp. & Czas konfliktu & \multicolumn{1}{|c|}{ Dotychczasowa potęga } & \multicolumn{1}{|c|}{$\begin{array}{c}\text { Wschodząca } \\
\text { potęga }\end{array}$} & $\begin{array}{c}\text { Rezultat } \\
\text { konfliktu }\end{array}$ \\
\hline 1 & I połowa XVI w. & Francja & Habsburgowie & wojna \\
\hline 2 & XVI-XVII w. & Habsburgowie & Imperium Osmanów & wojna \\
\hline 3 & XVII w. & Habsburgowie & Szwecja & wojna \\
\hline 4 & XVII w. & Dania & Anglia & wojna \\
\hline 5 & $\begin{array}{l}\text { Koniec XVII w. }- \\
\text { początek XVIII w. }\end{array}$ & Francja & Wielka Brytania & wojna \\
\hline 6 & $\begin{array}{l}\text { Koniec XVII w. }- \\
\text { początek XVIII w. }\end{array}$ & Zjednoczone Królestwo & Francja & wojna \\
\hline 7 & Połowa XIX w. & Zjednoczone Królestwo, Francja & Rosja & wojna \\
\hline 8 & XIX w. & Francja & Niemcy & wojna \\
\hline 9 & $\begin{array}{l}\text { Koniec XIX w. }- \\
\text { początek XX w. }\end{array}$ & Rosja, Chiny & Japonia & wojna \\
\hline 10 & Początek XX w. & Zjednoczone Królestwo & Stany Zjednoczone & bez wojny \\
\hline 11 & Początek XX w. & $\begin{array}{l}\text { Rosja, Zjednoczone Królestwo, } \\
\text { Francja }\end{array}$ & Niemcy & wojna \\
\hline 12 & Połowa XX w. & $\begin{array}{l}\text { Zwiázek Radziecki, Zjednoczone } \\
\text { Królestwo, Francja }\end{array}$ & Niemcy & wojna \\
\hline 13 & Połowa XX w. & Stany Zjednoczone & Japonia & wojna \\
\hline 14 & $1940-1980$ & Stany Zjednoczone & Związek Radziecki & bez wojny \\
\hline 15 & $1970-1980$ & Związek Radziecki & Japonia & bez wojny \\
\hline 16 & Lata 90. XX w. & Zjednoczone Królestwo, Francja & Niemcy & ? wojny \\
\hline 17 & I dekada XXI w. & Stany Zjednoczone & Chiny & bezina \\
\hline
\end{tabular}

Źródło: Opracowanie własne na podstawie: G. Allison, The Thucydides Trap: Are the U.S. and China Headed for War?, www.theatlantic.com (dostęp: 20.02.2021).

W ostatnich kilku latach Chiny stały się światowym liderem pod wieloma względami, np.: liczby użytkowników Internetu (w 2008 r.), produkcji samochodów (w 2009 r.), zużycia energii (w 2010 r.), posiadania najszybszego komputera świata (w 2010 r.), wniosków patentowych (w 2011 r.), wytwarzania smartfonów (w 2012 r.), liczby miliarderów (w 2015 r.), największej klasy średniej (w 2015 r.), badań nad sztuczną

33 G. Allison, The Thucydides Trap: Are the U.S. and China Headed for War?, www.theatlantic.com (dostęp: 20.02.2021). 
inteligencja (w 2016 r.). Elementem rywalizacji Chin ze Stanami Zjednoczonymi jest Inicjatywa Pasa i Szlaku - ważna także w kontekście globalnym ${ }^{34}$. Jednocześnie jest coś, co łączy obie rywalizujące z sobą gospodarki - dążenie do uczynienia własnego kraju wielkim oraz wzajemne obwinianie drugiego państwa o przeszkadzanie w realizacji tego celu. Bez nowej strategicznej wizji relacji amerykańsko-chińskich uniknięcie pułapki Tukidydesa może okazać się niemożliwe ${ }^{35}$. Zmiana lidera gospodarczego wpisywałaby się z kolei w teorię długich cykli koniunkturalnych Kondratiewa.

\section{Sroga zima w cyklu Kondratiewa}

W latach 20. XX w. Kondratiew przedstawił teorię, zgodnie z którą koniunktura gospodarcza od XVIII w. powtarzała się według regularnych, około półwiecznych cykli, z których każdy był zgodny z czterema porami roku. Propagatorem tej teorii był wspomniany J. Schumpeter, który twierdził, że podstawą tworzenia się długich cykli koniunkturalnych sa innowacje. Przyczynami cykli Kondratiewa oprócz innowacji są również: sfera pieniądza (inflacja lub deflacja), styl życia oraz ważne wydarzenia polityczne. Jeden długi cykl Kondratiewa dzieli się na dwie fazy, mające w przybliżeniu jednakową długość: fazę wzrostu oraz fazę stagnacji, które układają się w fale. Od schyłku fali trzeciej określa się je jako „postkondratiewowskie” (rys. 8).

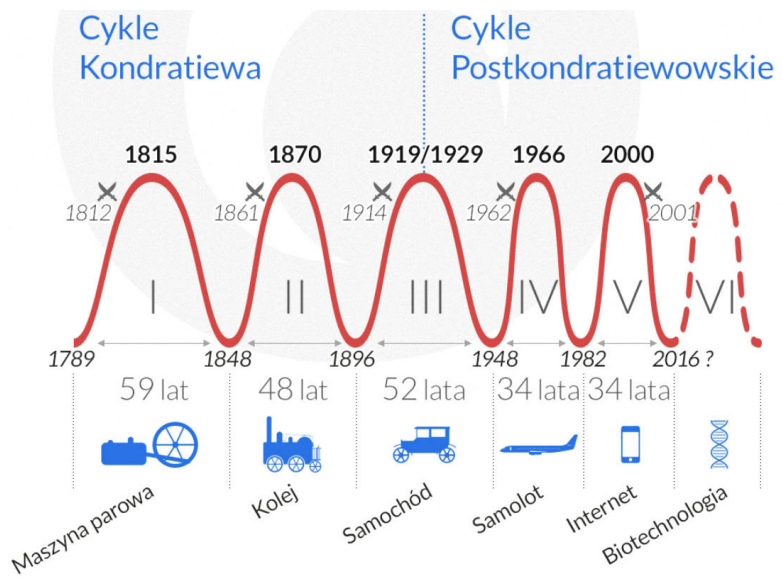

Rys. 8. Cykle Kondratiewa i postkondratiewowskie

Źródło: M. Pielach, Idzৃie kolejna gospodarcza zima, www.obserwatorfinansowy.pl (dostęp: 20.02.2021).

34 R. Ciborowski, E. Oziewicz, S. Pangsy-Kania, The Belt and Road Initiative - shared development or a threat for the world economy?, „European Research Studies Journal” 2021, vol. 24, Issue 1.

35 M. Jendrzejczak, Pułapka Tukidydesa. Czy amerykańsko-chinska rywalizacja doprowadzi do wojny?, www.m.pch24.pl (dostęp: 20.02.2021). 
Jak wynika z rys. 8, po II wojnie światowej cykle na skutek postępu technologicznego uległy skróceniu. Teoria Kondratiewa jest kontrowersyjna ze względu na zbyt małą liczbę powtarzalności, ale gdybyśmy przyęli, że jest prawdziwa, to obecnie znajdujemy się w szóstej fali, która skończy się ok. 2050 r. Zgodnie z tą teorią obecnie panuje w gospodarce światowej sroga zima, charakteryzująca się bessą na rynkach akcyjnych, kryzysami walutowymi, problemami banków z utrzymaniem płynności, pękającymi bańkami spekulacyjnymi. Katalizatorem tej fazy było ogłoszenie pandemii COVID-19. Po tej srogiej zimie ma nadejść wiosna stymulowana innowacjami. Być może siłą napędową kolejnej fali będą innowacje w zakresie energii? Energetyka wodorowa $z$ pewnością będzie ważna w transformacji energetycznej, szczególnie w kontekście rozwoju mobilności i dostaw energii elektrycznej. W tym celu konieczne będzie opracowanie tanich, szybkich i wydajnych metod, nie tylko produkcji, ale także magazynowania i transportu wodoru. Gdyby jednak przyjąć, że cykle nie ulegają skróceniu do 34 lat, to wówczas znajdujemy się obecnie w połowie piątej fali (tab. 3$)^{36}$. Siłą napędową fal Kondratiewa są głębokie społeczno-ekonomiczne przekształcenia, powstające w oparciu o innowacje technologiczne, które zmieniaja gospodarkę i politykę ${ }^{37}$.

Tab. 3. Fale Kondratiewa

\begin{tabular}{|l|l|l|l|l|}
\hline \multicolumn{1}{|c|}{ Cykle } & \multicolumn{1}{|c|}{ Lata } & $\begin{array}{c}\text { Czas trwania } \\
\text { cyklu }\end{array}$ & \multicolumn{1}{|c|}{ Przełomowa innowacja } & \multicolumn{1}{c|}{$\begin{array}{c}\text { Lider } \\
\text { gospodarczy }\end{array}$} \\
\hline Pierwsza fala & $1792-1847$ & 55 lat & $\begin{array}{l}\text { Maszyna parowa i rozwój } \\
\text { przemysłu włókienniczego }\end{array}$ & Wielka Brytania \\
\hline Druga fala & $1848-1893$ & 45 lat & Kolej i przetwórstwo stali & Wielka Brytania \\
\hline Trzecia fala & $1894-1939$ & 45 lat & $\begin{array}{l}\text { Elektryczność } \\
\text { i przemysł chemiczny }\end{array}$ & $\begin{array}{l}\text { Wielka Brytania } \\
\text { USA }\end{array}$ \\
\hline Czwarta fala & $1940-1990$ & 50 lat & $\begin{array}{l}\text { Motoryzacja } \\
\text { i przemysł petrochemiczny }\end{array}$ & USA \\
\hline Piąta fala & $1991-2040$ & 49 lat & $\begin{array}{l}\text { Internet i nowoczesne } \\
\text { technologie informacyjne } \\
\text { oraz komunikacyjne }\end{array}$ & USA \\
\hline Szósta fala & od 2041 & - & $\begin{array}{l}\text { Biotechnologia } \\
\text { i energia wodorowa? }\end{array}$ & $\begin{array}{l}\text { USA } \\
\text { Chiny? }\end{array}$ \\
\hline
\end{tabular}

Źródło: Opracowanie własne na podstawie: K. Górka, M. Luszczyk, Współcz̨esne tendencje roz̧woju gospodarczego regionu w kontekśsie teorii cykli koniunkturalnych, „Studia KPZK” 2014, nr 155, s. 87.

36 Ze względu na brak ściśle określonych ram czasowych kolejnych cyklów koniunkturalnych w tabeli zaprezentowane zostały lata trwania cykli, które są często powtarzającymi się w literaturze wynikami badań cyklów gospodarczych w skali globalnej.

37 G. Nowak, Cykle Kondratiewa. Światowa gospodarka w cyklicznej zimie?, www.amerbroker.pl (dostęp: 20.02.2021). 
Jak już wspomniano, każdy cykl Kondratiewa składa się z 4 pór roku: wiosny, która charakteryzuje się odradzaniem się gospodarki i szybkim jej wzrostem; lata - z wolniejszym wzrostem; jesieni, a wraz z nią spowolnienia gospodarczego i szybkiego wzrostu zadłużenia oraz zimy, czyli depresji gospodarczej (rys. 9). Tu z kolei wyróżniono 4 fale. Niezależnie jednak od różnych ujęć i podziału aktualnie świat znajduje się w fali określanej jako zima - ze wszystkimi jej konsekwencjami, w tym depresja gospodarcza, spadkiem długu względem PKB, hossą na rynku złota i spadkiem zaufania.

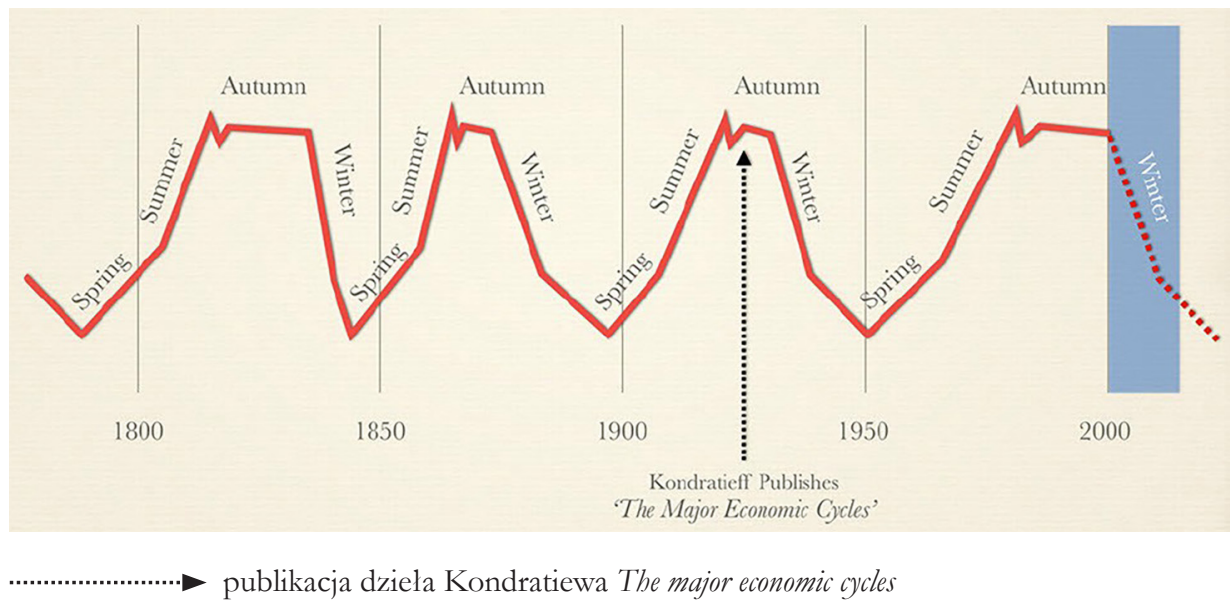

Rys. 9. Cztery pory roku w cyklu Kondratiewa

Źródło: Ch. Vermeulen, Kondratiev Wave - The Financial Winter Is Nearing!, www.marketoracle.co.uk (dostęp: 20.02.2021).

Jak wynika z danych zaprezentowanych na rys. 9, w roku 2000 rozpoczęła się zima, która trwa do tej pory. W czasie zimy często powstają innowacje w odpowiedzi na poszukiwanie rozwiązań tańszych, wydajniejszych i ogólnodostępnych, które będą nowym czynnikiem wzrostu kolejnej fali. Dno piątego cyklu przypada ok. 2020 r. i od tego czasu można spodziewać się na świecie istnienia napięć społecznych, politycznych, wzrostu tendencji dezintegracyjnych w Unii Europejskiej ${ }^{38}$, pogarszających się relacji Chin ze Stanami Zjednoczonymi i innymi krajami. Należy wziąc pod uwagę fakt, że w 2020 r. ogłoszono pandemię COVID-19. Zdarzenie to jest określane mianem „czarnego łabędzia”, ponieważ jego przebiegu nie można było przewidzieć, a jednocześnie ma ono ogromny wpływ na rzeczywistość społeczeństwa, gospodarki poszczególnych krajów i cała gospodarkę światowa. Wszystko wskazuje na to, że krzywa wychodzenia z pandemii będzie miała kształt

38 D. Kluska, Cykle Kondratiewa w gospodarce, https://analizy.investio.pl (dostęp: 20.02.2021). 
litery „U”, co determinuje odczuwanie jej skutków przez najbliższe lata. Recesja w Stanach Zjednoczonych, przy równoczesnym wzroście PKB Chin, może w tych okolicznościach przybliżyć o kilka lat moment zmiany lidera gospodarczego na świecie w zakresie supremacji innowacyjnej. Prawdopodobne jest, że stanie się to przed zakończeniem piątej fali cyklu Kondratiewa, czyli przed $2040 \mathrm{r}$.

Podkreślanie innowacyjności oraz jakości kosztem ilości w gospodarce stanowi immanentną część strategii rozwojowej przedstawionej w październiku 2017 r. podczas XIX Zjazdu Komunistycznej Partii Chin w Pekinie ${ }^{39}$. Prezydent Xi Jinping zaprezentował wówczas program, którego realizacja ma przekształcić Chiny w rozwinięty kraj socjalistyczny do $2035 \mathrm{r}$. oraz w czołowa globalną potęgę do $2050 \mathrm{r}$. Zgodnie z cyklem Kondratiewa urzeczywistnienie programu oznaczałoby, że szósta fala cyklu miałaby nowego lidera gospodarczego. Na tle zachodzących zmian w międzynarodowych stosunkach gospodarczych oraz zmian technologicznych wydaje się, że świat powoli wkracza w okres geopolitycznej zmiany. Proces ten będzie trwał przez najbliższe lata, a zwycięzcą po zakończeniu wojny toczącej się głównie w przestrzeni technologicznej mogą być Chiny, których droga do supremacji innowacyjnej zaczynała się od „made in China”. Wkrótce okaże się, czy „zdolność Chin do wymyślania i wprowadzania do użytku nowych technologii dojrzała na tyle, by porzucić zależność Chin od kradzieży tych technologii, wymuszonych transferów technologii oraz nieponoszenia przez chińskie firmy kosztów podobnych do tych, jakie ponoszą firmy działające na wolnym rynku"40.

\section{Podsumowanie}

Transformacja gospodarcza w Chinach trwa od ok. 40 lat. W tym czasie Państwo Środka należało do najszybciej rozwijających się gospodarek na świecie. Chiny to już nie tylko kraj taniej produkcji „made in China”. Stają się bowiem coraz bardziej innowacyjne, o czym świadczy wzrost miejsca w corocznym rankingu Global Innovation Index (GII). Global Innovation Index stanowi cenne źródło informacji, zwłaszcza w porównaniach międzynarodowych, potwierdzając, że wysoki stopień innowacyjności uzyskują te kraje, które charakteryzują się silną gospodarką mierzoną poziomem dochodów. Gospodarka Chin przewyższa jednak spodziewane wyniki parametru innowacyjności w odniesieniu do aktualnego poziomu rozwoju gospodarczego. Chiny, mimo że zajmują obecnie 14. miejsce w rankingu, charakteryzują się bardzo wysoką efektywnością gospodarki $(0,92)$, co daje im pierwszą lokatę w GII 2020 w ogólnym zestawieniu efektywności innowacyjnej. Szybki wzrost

\footnotetext{
39 L. Gacek, Nowe \{́ródta wŗrostu gospodarczego Chin: wiedza i innowacje, „Roczniki Humanistyczne” 2018, t. LXVI, z. 9.

40 J. Zhang, Rok 2021...
} 
innowacyjności chińskiej gospodarki potwierdza wzrost pozycji zajmowanej w rankingu w ciagu kilku lat - 7 lat temu było to miejsce 35., 5 lat temu -29., a 3 lata temu 22. Jeśli chodzi o subindeks wejścia (działania innowacyjne) to przewaga Stanów Zjednoczonych nad Chinami jest niezaprzeczalna, natomiast w przypadku subindeksu wyjścia (efekty innowacyjne) obie gospodarki w ostatnich 2 latach bardzo się do siebie zbliżyły.

Strukturalne procesy rywalizacji geopolitycznej pomiędzy Stanami Zjednoczonymi a Chinami są widoczne od kilku lat. Biorąc pod uwagę chiński ekspansjonizm, należy spodziewać się napiętych stosunków na linii Stany Zjednoczone - Chiny w najbliższych latach. W konflikcie tym, którego efektem jest trwająca od kilku lat wojna handlowa, coraz większego znaczenia nabiera geoekonomia, która podkreśla, że o pozycji kraju decyduje jego potencjał i efektywność gospodarcza. Ryzyko przekształcenia się rywalizacji między Stanami Zjednoczonymi a Chinami w wojnę, której skutkiem byłaby zmiana lidera w supremacji innowacyjnej, wynika z pułapki Tukidydesa. Ta wojna na polu technologicznym właśnie się toczy. Pułapka Tukidydesa oznacza nieuchronne zmierzenie się z sobą Stanów Zjednoczonych i Chin, ponieważ oba kraje walczą o te same zasoby. Jest ona naturalnym procesem ewolucji, której motorem napędowym jest postęp technologiczny.

Zmiana lidera gospodarczego, w kontekście pułapki Tukidydesa, wpisywałaby się również w teorię cykli koniunkturalnych Kondratiewa. Czynnikami tworzącymi fale Kondratiewa są głębokie przekształcenia społeczno-ekonomiczne, które powstaja w oparciu o innowacje technologiczne. Zgodnie z cyklem Kondratiewa w 2000 r. rozpoczęła się w gospodarce światowej zima, podczas której powstaja często nowe wynalazki - innowacje będące akceleratorem kolejnej fali.

Dażzenie Chin do supremacji innowacyjnej ma swoje odzwierciedlenie w strategiach rządowych, opartych na polityce protekcjonistycznej. Urzeczywistnienie programów i planów KPCh oznaczałoby, że szósta fala cyklu miałaby nowego lidera gospodarczego. Dodatkowo, z dynamicznie zmieniającej się rzeczywistości obejmującej cały świat, a wywołanej ogłoszeniem pandemii COVID-19 (wirus SARS-CoV-2), Chiny mogą wyjść wzmocnione.

\section{SUMMARY}

\section{FROM "MADE IN CHINA" TO "CREATED IN CHINA" - CHINA'S WAY TO INNOVATION SUPREMACY}

China is not only a country of cheap production ("Made in China"). China is becoming more and more innovative, as evidenced by its growing position in the annual Global Innovation Index (GII) ranking. Over the past decade, China has become an emerging superpower while the economic position of the United States and the European Union has 
weakened. The purpose of this article is to answer the question of whether the US innovation supremacy becoming the past. The role of China is growing as a result of departing from "Made in China" and illegally obtained technological solutions in favor of innovation and technologically advanced production "Created in China." Huawei is one of the most innovative companies in the world. The analysis is carried out in the context of the significance of the Thucydides trap in the technological war between the United States and China and the location of changes in the innovativeness of both countries in the aspect of the Kondratiev cycle. Additionally, China may come out stronger from the pandemic that has changed the whole world. 